\title{
Controlling Efficacy of Strobilurin Derivatives against Wheat Powdery Mildew and Eyespot
}

\author{
Tsuneo ICHIBA, ${ }^{*, \#}$ Tetsuya InUta,, Yukio Horita, Motomu NiIKAWA \\ and Michio MASUKO \\ Abrahi Laboratories, Shionogi and Co., Ltd., Koka-cho, Koka-gun, Shiga 520-3423, Japan
}

(Received August 22, 2001 ; Accepted December 27, 2001)

\begin{abstract}
Strobilurins are active against a wide range of diseases in laboratory tests, but do not always show the same level of activity under field conditions. We studied the differences in fungicidal activity under laboratory and field conditions of strobilurins and DMIs (14-demethylation inhibitor of elgosterol biosynthesis pathway) against wheat powdery mildew and eyespot, focussing on the systemicity of the compounds. Against wheat powdery mildew, the activity of the test compounds in the field differed from that in the laboratory. In the field, kresoxim-methyl, (E)-2-[2-(3-trifluoromethyl-5-chloropyridin-2-yloxymethyl)phenyl]-2-methoxyimino- $N$-methylacetamide and triadimefon, which have high level of both systemic activity and vapor-phase activity, showed excellent efficacy to control wheat powdery mildew. The effect is presumably due to the uniform coverage of the leaf surface, even leaves that emerged and developed after fungicide application. On the other hand, against wheat eyespot, $(E)-2-[2-(2$, 5-dimethylphenoxymethyl)phenyl]-2-methoxyimino- $N$-methylacetamide (SSF-129) and prochloraz showed excellent activity in the field, despite being ineffective against powdery mildew. These compounds had strong mycelial growth inhibitory activity, limited systemic activity and no vapor-phase activity. Therefore, it is assumed that these two fungicides remain in the area where they are sprayed, and show excellent control of eyespot, the symptom of which develop in a limited area of the stem base of wheat seedlings.
\end{abstract}

Key words: methoxyiminoacetamide derivatives, fungicide, strobilurin analogue, wheat powdery mildew, wheat eyespot.

\section{INTRODUCTION}

In our previous studies of the structure-activity relationships of methoxyiminoacetamide derivatives, we synthesized several compounds with excellent fungicidal activity against various diseases by foliar application including $(E)-2-[2-($ substituted phenoxymethyl)phenyl]2-methoxyimino- $N$-methylacetamide derivatives ${ }^{1)}$ and (E)-2-[2-(substituted pyridyloxymethyl)phenyl]-2methoxyimino- $N$-methylacetamide derivatives. ${ }^{2)}$ From similarities in chemical structure, the compounds were classified as strobilurin analogues, suggesting that they have the same mode of action as strobilurins. ${ }^{3-6)}$ Though active against a wide range of diseases in laboratory tests, these compounds are not always as effective in the field. Such differences in fungicide performance

\footnotetext{
* To whom correspondence should be addressed.

E-mail: Tsuneo.Ichiba @ aventis.com

* Present address: Aventis CropScience Shionogi Co. Ltd., Naruto-machi, Sanbu-gun, Chiba 289-1326, Japan
}

between laboratory and field tests are probably due to complex interactions of chemical, environmental and biological factors, such as the water solubility or $\log P$ value of the compounds, differences in weather conditions between the laboratory and field, differences in systemic activities among the compounds and differences in infection and manner of development among diseases. Wheat powdery mildew and eyespot are important diseases throughout the world. ${ }^{7-11)}$ Symptom of wheat powdery mildew develops on the leaf surface due to the growth of mycelia, while symptom of wheat eyespot develops because of invasion of the mycelia into the first node of the stem. This paper deals with differences in fungicidal activity in laboratory tests and under field conditions of strobilurin and DMIs against wheat powdery mildew and eyespot, in terms of the systemicity of compounds. 


\section{MATERIALS AND METHODS}

\section{Chemicals}

(E)-2-[2-(2,5-Dimethylphenoxymethyl)phenyl]-2methoxyimino- $N$-methylacetamide (SSF-129), (E)-2[2-(3-trifluoromethyl-5-chloropyridin-2-yloxymethyl) phenyl]-2-methoxyimino- $N$-methylacetamide (Compound A, Fig. 1), kresoxim-methyl and azoxystrobin were synthesized, and prochloraz was extracted from a product at Aburahi Laboratories, Shionogi Co., Ltd. (Shiga, Japan). Triadimefon of analytical grade was purchased from Wako Chemical Co., Ltd. (Kyoto, Japan).

\section{2. $\quad$ Plant Materials}

Wheat (Triticum aestivum L. cv. Nohrin-61) and cucumber (Cucumis sativus L. cv. Sagami-hanjiro) seedlings were used for the tests. Seeds were sown in plastic cups containing sterilized soil and grown in a greenhouse. Two weeks after sowing, the wheat seedlings were tested for fungicidal activity against wheat powdery mildew and subjected to a systemicity assay. The cucumber seedlings were used for vapor-phase activity tests.

\section{Fungicidal Activity Assay}

The activity against wheat powdery mildew was assessed by preventive foliar application. The test compounds were dissolved in a small amount of $N, N$ dimethylformamide (DMF) and diluted to appropriate concentrations with distilled water containing sticker. The test solutions or suspensions were sprayed onto the host plant $24 \mathrm{hr}$ before inoculation. Inoculation was carried out by sprinkling the conidia of Blumeria graminis (de Candolle) Speer f. sp. tritici over the wheat seedlings, to which the compound had been applied. The inoculated seedlings were kept in a greenhouse at $22 \pm 2^{\circ} \mathrm{C}$ for ten days, and infected leaf area was assessed and percent of control was calculated.

\section{Systemic Activity Test}

To assess the systemic activity of the compounds in wheat, the first leaves were kept horizontally, and a $10 \mu \mathrm{l}$

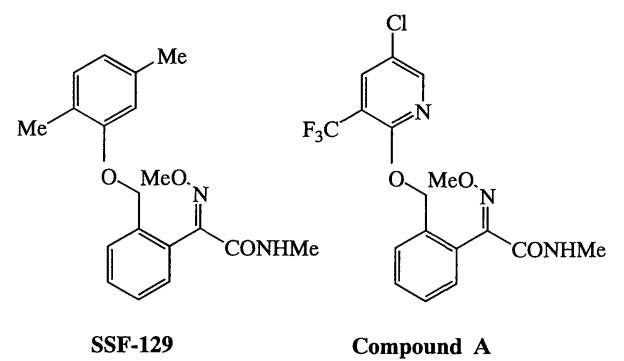

Fig. 1 Structures of SSF-129 and Compound A. droplet of the test solution of appropriate concentration was placed on the upper surface (adaxial surface) of the leaf. Inoculation was carried out as described above. Ten days after treatment, the length of the inhibition zone was measured.

\section{Vapor-phase Activity Assay}

The vapor-phase activity of the compounds was assessed using cucumber powdery mildew on the cucumber cotyledon. Inoculations were carried out by spraying the conidial suspension of Sphaerotheca fuliginea (Schlechtend: Fr.) Pollacci onto the adaxial surface of the cucumber cotyledon. Twenty-four hours after the inoculation, a $10 \mu \mathrm{l}$ droplet of the test solution was spotted onto a plastic disk $(6 \mathrm{~mm}$ in diameter $)$ placed at the center of the cucumber cotyledon. After the droplet had dried, seedlings were kept in separate plastic boxes at $22 \pm 2^{\circ} \mathrm{C}$. Ten days after the inoculation, the size of the inhibition zone around the plastic disk was measured.

\section{Evaluation of Activity against Wheat Powdery Mildew under Field Conditions}

The activity of the test compounds against wheat powdery mildew was evaluated by artificial inoculation under field conditions in 1995-1996. Wheat seeds were sown on Dec. 18, 1995 . On Mar. 26, 1996, inoculation was carried out by sprinkling the conidia of $B$. graminis, which had previously sporulated on the wheat seedlings. The compound dissolved in DMF (final concentration $1 \%)$ and diluted with water containing sticker was applied to the test plants with hand-held sprayers on Apr. 10, 1996. Each plot was $2 \mathrm{~m}^{2}$ with three replications and the application volume was $300 \mathrm{ml}$ (at $100 \mathrm{ppm}$ ) and $60 \mathrm{ml}$ (at $500 \mathrm{ppm}$ ) per plot. Evaluation was carried out on Apr. 24 and May 8 (14 and 28 days after the last application, respectively) in 1996 by observing the infected area of top three leaves of 30 stems in each plot.

\section{Inhibition of Mycelial Growth of Pseudocercospor- ella herpotrichoides}

Test compounds dissolved in acetone were added to potato dextrose agar (PDA) medium kept at $50^{\circ} \mathrm{C}$ after autoclaving. The final concentration of acetone was 0.3\%. Pseudocercosporella herpotrichoides (Fron) Deighton: W-type was precultured on PDA medium, and a mycelial disk (4 $\mathrm{mm}$ in diameter) was cut from the tip of the mycelial mat, and placed on PDA medium containing the test compound. After 14 days incubation at $20^{\circ} \mathrm{C}$, the diameter of the mycelial mat was measured.

\section{Evaluation of Activity against Wheat Eyespot under Field Conditions}

The controlling activities of the selected compounds on wheat eyespot were evaluated by artificial inoculation under field conditions in 1994-1995 and 1995-1996. 
Wheat seeds were sown on Nov. 14, 1994 and Nov. 2, 1995. Mycelia of $P$. herpotrichoides precultured on potato dextrose broth in an orbital shaker at $25^{\circ} \mathrm{C}$ for 10 days, were inoculated onto autoclaved oat seeds and cultured at $25^{\circ} \mathrm{C}$ for 14 days. Inoculation was carried out on Feb. 16, 1995 and Feb. 17, 1996, by applying the inoculum $\left(62.5 \mathrm{ml} / \mathrm{m}^{2}\right)$ to the basal part of the stem. The compounds were prepared as described above and applied with a hand-held sprayer twice in the first trial on Mar. 20 and Apr. 3, 1995, and once in the second trial on Mar. 13, 1996. Each plot measured $2.4 \mathrm{~m}^{2}(0.8 \times 3 \mathrm{~m})$ with two (in the first trial) or three (in the second trial) replications, and the application volume was $208 \mathrm{ml} / \mathrm{m}^{2}$. Evaluation was carried out on May 9, 1995 and May 15, 1996 by observing 60 culms in each plot, and the degree of infection was calculated as follows:

Degree of infection $=\Sigma$ (Number of culms belonging to each Disease Index $X$ Disease Index $) \times 100 /($ Total number of culms assessed $X$ 4)

The Disease Index estimated from lesions on the culm was scored as follows.

Disease Index Degree of infection

$0 \quad$ No symptoms on the culm

1 Less than $1 / 2$ of the culm was covered with lesions

2 More than $1 / 2$ of the culm was covered with lesions

3 Lesions surround the culm, but only part of the internode

4 All of the culm was covered with lesions

\section{RESULTS AND DISCUSSION}

\section{Controlling Activity against Wheat Powdery Mil- dew (Pot Test)}

Controlling activities of SSF-129, Compound A and other authentic compounds against wheat powdery mil- dew are shown in Table 1. Among the strobilurin analogues, SSF-129 and Compound A exhibited strong activity with $\mathrm{EC}_{50}$ values of 0.07 and $0.05 \mathrm{ppm}$, respectively. Azoxystrobin and kresoxim-methyl exhibited almost the same level of activity with $\mathrm{EC}_{50}$ values of $1.39-0.95 \mathrm{ppm}$. Among the DMIs, fenarimol showed the highest level of activity with an $\mathrm{EC}_{50}$ value of 0.58 ppm, while triadimefon and prochloraz were less active.

\section{Systemic Activity and Vapor Activity}

The systemic activity of the compounds was assessed by inhibition zone assay on the wheat cotyledon with $31.3 \mathrm{ppm}$ spot application using wheat powdry mildew. The results are shown in Fig. 2. Despite having strong fungicidal activity in the pot tests, SSF-129 and Compound A showed quite a different systemic performance. The inhibition zone formed by Compound $\mathrm{A}$ as well as azoxystrobin expanded extensively toward the tip of the wheat leaf but little toward the base of the leaf. On the other hand, SSF-129 demonstrated less diffusion of the inhibition zone either toward the tip or base of the leaf. The inhibition zone formed by kresoxim-methyl expanded in both directions.

In the pot test, the fungicidal activity of triadimefon was obviously inferior to that of fenarimol, but the inhibition zone was larger toward the leaf tip with

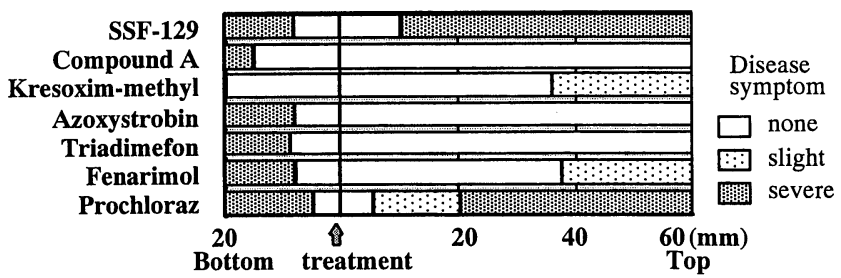

Fig. 2 Systemic activities of test compounds. Compounds were applied by spotting of $10 \mu \mathrm{l}(31.3 \mathrm{ppm})$ on wheat first leaves kept horizontally. Twenty-four hours after the application, conidia of wheat powdery mildew were inoculated onto the first leaves. Ten days after the inoculation, the inhibition zone was measured $(n=9)$.

Table 1 Fungicidal activities of test compounds against wheat powdery mildew by preventive application (Pot tests).

\begin{tabular}{|c|c|c|c|c|c|c|c|c|}
\hline \multirow{2}{*}{ Compound } & \multicolumn{7}{|c|}{ Percent of Control } & \multirow{2}{*}{$\begin{array}{c}\mathbf{E C}_{50} \\
(\mathrm{ppm})\end{array}$} \\
\hline & 125 & 31.3 & 7.8 & 2.0 & 0.5 & 0.125 & $0.06(\mathrm{ppm})$ & \\
\hline SSF-129 & - & 100 & 100 & 98 & 94 & 79 & 22 & 0.07 \\
\hline Compound A & - & 100 & 100 & 96 & 89 & 60 & 50 & 0.05 \\
\hline Kresoxim-methy & 100 & 92 & 86 & 68 & 39 & 14 & - & 0.95 \\
\hline Azoxystrobin & 95 & 87 & 85 & 64 & 35 & 5 & - & 1.39 \\
\hline Triadimefon & 99 & 94 & 82 & 57 & 30 & 0 & - & 1.60 \\
\hline Fenarimol & 98 & 98 & 94 & 84 & 50 & 0 & - & 0.58 \\
\hline Prochloraz & 92 & 70 & 70 & 57 & 23 & 0 & - & 3.39 \\
\hline
\end{tabular}

Conidia of $B$. graminis f. sp. tritici were sprinkled onto two-week-old

wheat seedlings at $24 \mathrm{hr}$ after treatment with test compounds.

Infected leaf area was assessed 10 days after inoculation.

Data are means of more than three experiments. 
Table 2 Vapor-phase activity of test compounds against cucumber powdery mildew.

\begin{tabular}{lcc}
\hline \multirow{2}{*}{ Compound } & \multicolumn{2}{c}{ Inhibition zone (length $\times$ width mm) } \\
\cline { 2 - 3 } SSF-129 & $7.8 \mathrm{ppm}$ & $2.0 \mathrm{ppm}$ \\
Compound A & $\mathrm{ND}$ & $\mathrm{ND}$ \\
Kresoxim-methyl & $8.9 \times 10.7$ & $\mathrm{ND}$ \\
Azoxystrobin & $20<\times 20<$ & $12.7 \times 13.5$ \\
Triadimefone & $\mathrm{ND}$ & $\mathrm{ND}$ \\
Fenarimol & $20<\times 20<$ & ND \\
Prochloraz & $\mathrm{ND}$ & ND \\
\hline
\end{tabular}

Vapor-phase activity was assesed using cucumber powdery mildew.

The cucumber cotyledons were inoculated with $S$. fuliginea.

Twenty-four hours after inoculation, a $10 \mu \mathrm{l}$ droplet of each compound was spotted on a plastic disk ( $6 \mathrm{~mm}$ in diameter) placed in the center of the inoculated cotyledon.

The size of the inhibition zone was measured 10 days after inoculation.

Data are means of 4 replications.

Table 3 Controlling efficacy of compounds against wheat powdery mildew under field conditions (1996).

\begin{tabular}{|c|c|c|c|c|c|c|}
\hline \multirow[b]{2}{*}{ Compound } & \multirow{2}{*}{$\begin{array}{l}\text { Conc. } \\
\text { (ppm) }\end{array}$} & \multirow{2}{*}{$\begin{array}{c}\text { Spray } \\
\text { volume } \\
(1 / a)\end{array}$} & \multicolumn{2}{|c|}{ Apr. 24} & \multicolumn{2}{|c|}{ May 8} \\
\hline & & & $\begin{array}{l}\text { Infected } \\
\text { area (\%) }\end{array}$ & $\begin{array}{c}\% \text { of } \\
\text { Control }\end{array}$ & $\begin{array}{l}\text { Infected } \\
\text { area (\%) }\end{array}$ & $\begin{array}{c}\% \text { of } \\
\text { Control }\end{array}$ \\
\hline SSF-129 & 100 & 15 & 9.3 cde & 63.0 & 4.5 bcde & 78.5 \\
\hline Compound A & 100 & 15 & $3.5 \mathrm{ef}$ & 85.9 & 3.1 cde & 85.3 \\
\hline Kresoxim-methy & 100 & 15 & 7.9 def & 68.6 & $1.3 \mathrm{e}$ & 93.7 \\
\hline Fenarimol & 100 & 15 & $14.5 \mathrm{bc}$ & 42.1 & $8.6 \mathrm{~b}$ & 58.3 \\
\hline Triadimefone & 100 & 15 & $2.0 \mathrm{f}$ & 92.0 & $2.0 \mathrm{de}$ & 90.2 \\
\hline SSF-129 & 500 & 3 & $10.8 \mathrm{~cd}$ & 57.0 & $7.2 \mathrm{bcd}$ & 65.2 \\
\hline Compound A & 500 & 3 & 5.9 def & 76.4 & 3.4 bcde & 83.8 \\
\hline Kresoxim-methy & 500 & 3 & $2.7 \mathrm{f}$ & 89.2 & 0.9 e & 95.5 \\
\hline Fenarimol & 500 & 3 & $18.7 \mathrm{~b}$ & 25.4 & $8.4 \mathrm{bc}$ & 59.4 \\
\hline Triadimefone & 500 & 3 & $1.9 \mathrm{f}$ & 92.4 & $2.7 \mathrm{de}$ & 87.2 \\
\hline Control & - & - & $25.1 \mathrm{a}$ & 0.0 & $20.7 \mathrm{a}$ & 0.0 \\
\hline
\end{tabular}

Sowing: Dec. 18, 1996. Inoculation: Mar. 28,1997. Application: Apr. 10.

Evaluation: Apr. 24 and May 8.

triadimefon than fenarimol. Prochroraz produced the smallest inhibition zone. These results suggested that Compound $\mathrm{A}$ and azoxystrobin as well as triadimefon are easily incorporated into the leaf through the epidermal cells and translocated apoplastically with the transpiration stream. On the other hand, SSF-129 as well as prochloraz, which demonstrated strong fungicidal activity, exhibited little apoplastic and symplastic movement. The differences in movement between such structurally similar compounds would be due to differences in watersolubility or $\log P$ values. Kresoxim-methyl produced a large inhibition zone toward the tip and basal part of the wheat leaf, suggesting that the compound moved apoplasticaly and symplasticaly, or exhibited its fungicidal effect by vapor-phase activity. The fungicidal activities of the test compounds in the vapor phase are shown in Table 2. Kresoxim-methyl and triadimefon produced a large sphere of inhibition around the plastic plate. Compound A showed slight vapor-phase activity, and the rest did not show any vapor activity. These results suggested that the compounds which exhibit good vaporphase activity are more effective under field conditions against diseases such as powdery mildew, the symptoms of which develop on the leaf surface of the host plant.

\section{Controlling Activity against Wheat Powdery Mil- dew under Field Conditions}

The controlling activities of the compounds against wheat powdery mildew were assessed under field conditions in 1996 (Table 3). The field trial was carried out under high disease pressure. Kresoxim-methyl showed the highest efficacy among the strobilurin analogues despite that its activity was inferior to that of SSF-129 and of Compound $\mathrm{A}$ in the pot test. Compound $\mathrm{A}$ demonstrated good control with low concentration/high volume (100 ppm, 15 l/a) and high concentration/low volume $(500 \mathrm{ppm}, 3 \mathrm{l} / \mathrm{a})$ application. On the other hand, SSF-129 demonstrated good control at low concentration/high volume, but slightly inferior control at high concentration/low volume, even though the a dosages of 
the active ingredient were the same. Kresoxim-methyl exhibited excellent efficacy even on the leaves of the upper part of the seedlings where the fungicide was not applied. However, despite controlling the disease on the fungicide-treated lower leaves, SSF-129 could not prevent disease development on the leaves of the upper part of the plant. The same tendency was observed among the DMI compounds. Triadimefon, whose fungicidal activity in the pot test was inferior but whose systemic activity was superior to that of fenarimol, exhibited excellent control in the field trial. Based on these experimental results and a distinctive feature of the disease, that the pathogen is entirely superficial, we assumed that systemic activity or vapor-phase activity contributes to fungicidal performance against powdery mildew under field conditions. These activities are presumably due to the uniform coverage of the leaf surface, even on the leaves that emerged and developed after fungicide application, through translocation by the transpiration stream or diffusion in the vapor-phase of the active ingredient.

\section{Inhibitory Activity on Mycelial Growth of P. her- potrichoides}

The inhibitory activity of the compounds on the mycelial growth of $P$. herpotrichoides was examined in the presence or absence of flavone in vitro (Table 4). All of the strobilurin analogues exhibited some activity, but none could prevent mycelial growth completely even at $125 \mathrm{ppm}$ without flavone. SSF-129 showed the strongest activity and azoxystrobin the weakest. In all cases, the inhibitory activity was enhanced by flavone, suggesting that the mechanism of action of each analogue is the same as that of metominostrobin; that is, inhibition of the cytochrome $b_{1}$ complex of the mitochondrial respiratory chain. $^{12-15)}$ These observations indicated that flavone blocked an alternative pathway or induction in response to a blockage of the cytochrome pathway by strobilurins. It is suggested that strobilurins can control the development of eyespot in conjunction with plant components such as flavonoids.

Among the DMI fungicides, prochloraz exhibited the

Table 4 Inhibitory activity on mycelial growth of $P$. herpotichoides.

\begin{tabular}{lccccc}
\hline \multirow{2}{*}{ Compound } & \multicolumn{2}{c}{ without flavone } & & \multicolumn{2}{c}{ with flavone 50 ppm } \\
\cline { 2 - 3 } \cline { 5 - 6 } SSF-129 & $125<$ & 0.13 & & 1 & 0.03 \\
Compound A & $125<$ & 0.33 & & 1 & 0.08 \\
Kresoxim-methyl & $125<$ & 0.79 & & 5 & 0.11 \\
Azoxystrobin & $125<$ & 3.20 & & 25 & 0.41 \\
Fenarimol & 25 & 1.02 & & - & - \\
Triadimefon & $125<$ & 7.81 & & - & - \\
Prochloraz & 5 & 0.06 & & - & - \\
Thiophanate-methyl & 25 & 1.18 & & - & - \\
\hline
\end{tabular}

Mycelial disks ( $4 \mathrm{~mm}$ in diameter) of $\mathrm{W}$-type of $P$. herpotrichoides were placed on PDA medium containing each test compound and incubated at $20^{\circ} \mathrm{C}$.

After 14 days incubation, the diameter of the mycelial mat was measured.

Data are means of three replications.

Table 5 Controlling efficacy of compounds against wheat eyespot under field conditions (1995 \& 1996).

\begin{tabular}{|c|c|c|c|c|c|c|c|}
\hline \multirow[b]{2}{*}{ Compound } & \multirow{2}{*}{$\begin{array}{l}\text { Conc. } \\
\text { (ppm) }\end{array}$} & \multicolumn{3}{|c|}{$1995^{\text {a) }}$} & \multicolumn{3}{|c|}{$1996^{\mathrm{b})}$} \\
\hline & & $\begin{array}{l}\text { Infected } \\
\text { stem (\%) }\end{array}$ & $\begin{array}{c}\text { Disease } \\
\text { incidence }\end{array}$ & $\begin{array}{c}\% \text { of } \\
\text { Control }\end{array}$ & $\begin{array}{l}\text { Infected } \\
\text { stem (\%) }\end{array}$ & $\begin{array}{c}\text { Disease } \\
\text { incidence }\end{array}$ & $\begin{array}{c}\% \text { of } \\
\text { Control }\end{array}$ \\
\hline \multirow[t]{2}{*}{ SSF-129 } & 100 & 50.0 & 15.0 & 65.5 & 57.2 & 21.7 & 66.6 \\
\hline & 400 & 11.7 & 2.9 & 93.3 & 15.6 & 4.9 & 92.5 \\
\hline \multirow[t]{2}{*}{ Compound A } & 100 & 70.8 & 22.1 & 49.2 & - & - & - \\
\hline & 400 & 49.2 & 14.2 & 67.4 & - & - & - \\
\hline Kresoxim-methyl & 200 & - & - & - & 74.4 & 39.6 & 39.1 \\
\hline \multirow[t]{2}{*}{ Prochloraz } & 100 & 58.3 & 18.1 & 58.4 & 56.7 & 19.6 & 69.8 \\
\hline & 400 & 29.2 & 7.9 & 81.8 & 24.4 & 7.2 & 88.9 \\
\hline Control & - & 93.3 & 43.5 & - & 97.2 & 65 & - \\
\hline
\end{tabular}

a)Sowing: Nov. 14, 1994. Inoculation: Jan. 17, 1995. Application: May 20 and Apr. 3. Evaluation: May 9. b)Sowing: Nov. 2, 1995. Inoculation: May 13, 1996. Application: May 13. Evaluation: May 15.

All compounds were applied at $20.8 \mathrm{1} / \mathrm{a}$. 
highest level of activity with an $\mathrm{EC}_{50}$ value of $0.06 \mathrm{ppm}$.

\section{Controlling Activity against Wheat Eyespot under Field Conditions}

Controlling activity of the test compounds against wheat eyespot under field conditions are shown in Table 5. SSF-129 exhibited excellent efficacy at $400 \mathrm{ppm}$ in both 1995 and 1996. Compound A seemed to be inferior to SSF-129 and prochloraz but its efficacy was acceptable at $400 \mathrm{ppm}$. The activity of kresoxim-methyl was inferior to that of any other compound. Eyespot is an important disease affecting the base of the wheat plant. Lesions begin to develop superficially on the leaf sheath near the soil surface, and the sheath collapses with time. A lesion then develops around the culm and penetrates the center of the culm. However, they are restricted to the 1st and /or 2nd nodes of the plant, and mycelia do not penetrate higher than $4-5 \mathrm{~cm}$ above the soil surface. SSF-129 did not exhibit good control of wheat powdery mildew under field conditions despite having excellent activity in the pot test, whereas it exhibited excellent control of wheat eyespot, possibly due to the different features of disease development. SSF-129 as well as prochloraz showed limited systemic activity and no vapor-phase activity. Therefore, these two fungicides will remain in the area where they are sprayed, and show excellent control of eyespot.

These results suggested that the systemic activity and vapor-phase activity of the compound in addition to the basic antifungal activity, and also the manner of disease development, influence the performance of fungicides under field conditions.

\section{ACKNOWLEDGMENTS}

We thank Dr. Nobuo Miki and Dr. Reiji Takeda of Shionogi $\&$ Co., Ltd., for helpful advice, and all the staff of the organic synthesis and agrochemical groups of Aburahi Laboratories for their invaluable support in this study.

\section{REFERENCES}

1) H. Takenaka, Y. Hayase, R. Hasegawa, T. Ichiba, M. Masuko, A. Murabayashi \& R. Takeda: J. Pesticide Sci. 23, 379-385 (1998)

2) H. Takenaka, M. Ichinari, Y. Hayase, M. Niikawa, T. Ichiba, M. Masuko, Y. Hayashi \& R. Takeda: J. Pesticide Sci. 23, 107-112 (1998)

3) W. F. Becker, G. Vonjagow, T. Anke \& W. Steglich: FEBS Lett. 132, 329-333 (1981)
4) E. Ammermann, G. Lorenz, K. Schlber, B. Wenderoch, H. Sauter \& C. Renzes: Proc. Brighton Crop Prot. Conf. Pests Dis. 1, 403-410 (1992)

5) J. R. Godwin, V. M. Anthony, J. M. Clough \& C. R. A. Godfrey: Proc. Brighton Crop Prot. Conf. Pests Dis. 1, 435442 (1992)

6) T. Kataoka, Y. Hayase, M. Masuko, M. Niikawa, M. Ichinari, H. Takenaka, N. Tanimoto, Y. Hayashi \& R. Takeda: J. Pesticide Sci. 23, 95-106 (1998)

7) H. Furuya: Ann. Phytopath. Soc. Jpn. 50, 77-81 (1984)

8) H. Ozaki: Plant Protect. 44, 210-213 (1990)

9) R. J. Cook, R. W. Polley \& M. R. Thomas: Crop Protect. 10, 504-508 (1991)

10) D. R. Jones: Plant Pathol. 43, 831-846 (1994)

11) M. Ozaki: Plant Protect. 54, 175-178 (2000)

12) A. Mizutani, H. Yukioka, H. Tamura, N. Miki, M. Masuko \& R. Takeda: Phytopathol. 85, 306-311 (1995)

13) A. Mizutani, N. Miki, H. Yukioka, H. Tamura \& M. Masuko: Phytopathology 86, 295-300 (1996)

14) H. Tamura, A. Mizutani, H. Yukioka, N. Miki, K. Ohoba \& M. Masuko: Pestic. Sci. 55, 681-686 (1999)

15) T. Ichiba, K. Kumano, H. Kashino, K. Nanba, A. Mizutani \& N. Miki: J. Pesticide Sci. 25, 398-401 (2000)

\section{要 約}

\section{ストロビルリン系化合物のコムギうどんこ病および 眼紋病に対する防除効果}

市場常男，狗田鉄也，堀田幸夫 新川 求, 益子道生

数種のストロビルリン系化合物および DMI 剤を用い室 内における殺菌活性と戋場における防除効果の関係につい て,コムギうどんこ病およびコムギ眼紋病を対象として比 較検討した．固場におけるコムギうどんこ病に対する防除 効果は, 室内試験における殺菌活性と一致せず, 浸透移行 性が高く, ベーパーによる活性が認められたクレソキシム

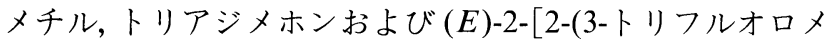
チル-5-クロロピリジン-2-イルオキシメチル)フェニル]-2メトキシイミノ- $N$-メチルアセトアミドの 3 剂が高い防除 効果を示し, 浸透移行またはべーパーにより新たに展開す る葉を保護することが重要な要素と考えられた。一方, 眼 紋病に対しては高い菌系伸長阻害活性を示し, 浸透移行性


ニル]-2-メトキシイミノ- $N$-メチルアセトアミド (SSF-129) およびプロクロラズが, 圑場においても高い防除効果を示 し，菌系伸長阻害活性が高くかつ付着した化合物が長期に 散布部位に残ることが重要な要素と考えられた。 